\title{
Antibacterial activity, antibiotic susceptibility and probiotic use of lac- tic acid bacteria (LAB) in Persian sturgeon (Acipenser persicus)
}

\author{
M Soltani $^{1}$, A Shenavar Masouleh ${ }^{1,2}$, M Ahmadi $^{2}$, M Pourkazemi ${ }^{1}$ and A Taherimirghaed ${ }^{2}$ \\ ${ }^{1}$ Department of Aquatic Animal Health, Faculty of Veterinary Medicine, University of Tehran; Center of excel- \\ lence of aquatic animal health, University of Tehran, Iran \\ ${ }^{2}$ International Sturgeon Research Institute, Rasht, Iran
}

Recived: June 2015 Accepted: November 2015

\begin{abstract}
Growth behavior of five lactic acid bacteria previously isolated from Persian sturgeon (Acipenser persicus), were evaluated at different $\mathrm{pH}$, temperature and salt concentrations. Also, antibacterial activity of extracellular products (ECPs) of this LAB were assessed to Aeromonas hydrophila. Further, their antibiotic susceptibility was determined with some commonly used antibiotics in aquaculture. In an in vivo work the effect of Lactococcus lactis as the supplementary diet was evaluated on growth performance of Persian sturgeon for a period of 56 days. Strong growth of all $\mathrm{LAB}$ were seen at 20 and $30^{\circ} \mathrm{C}$, as well as 40 and $80 \mathrm{~g} \mathrm{~L}-1 \mathrm{NaCl}$. The LAB ECPs exhibited varied results of antagonism to the A. hydrophila with maximum activity observed at temperature between 25 and $30^{\circ} \mathrm{C}$. Also, the higher antagonistic activity was observed for ECPs of $W$. cibaria, P. pentosaceus, and L. lactis at $\mathrm{pH} 9$. Both $W$. cibaria and E. faecalis were resistance to oxytetracycline, erythromycin, trimethoprim sulfamethoxazol, enrofloxacin, florfenicol, and flumequine, while $L$. lactis was sensitive to oxytetracycline, erythromycin, enrofloxacin, florfenicol. These results showed that use of L. lactis can act as a positive probiotic in Persian sturgeon feed via improvement of fish growth performance, feed efficiency and fish health.
\end{abstract}

Keywords: sturgeon, health, Lactococcus lactis, probiotic.

Correspondence M Soltani, Department of Aquatic Animal Health, Faculty of Veterinary Medicine, University of Tehran (e-mail: msoltani@ut.ac.ir)

\section{Introduction}

Nowadays, a high request for consumption of aquaculture production has been significantly increased together with a remarkable decrease in the wild aquatic animal stock resources. Appllication of new commercial aquatic animal species and aquaculture methods are generally raised some new diseases and economical problems (Oidtmann, Thrush, Denham $\&$ Peeler 2011). Therefore, there is a highly demand for new methods for prevention and treatments of fish diseases in aquaculture industry in order to increase the cost-benefit for the farmers.

Application of antibiotics for treatment and control of fish diseases can cause a harmful effect for both the environment and consumer. The residual of chemical substances such as antibiotics could be appeared as some drug resistances in both animal and human bacterial flora. Hence to improve the optional tools for prevention of fish diseases it should be deflected to find some new health managements such as enhancing the husbandry, the water quality, decreasing the fish densities, improveding food efficacy, vaccines, probiotics and immunostimulants (Sharifuzzaman \& Austin 2009). Although vaccines and chemotherapeutic treatments have been used for protection of fish from bacterial diseases but sometimes need more therapeutics to prevent or treat fish infections because vaccination process is frequently incapable in immature fish (Balcazar, Vendrell, Blas, Ruiz-Zarzuela, Múzquiz \& Gironés 2008).

Intensive sturgeon culture are exposed to stressful conditions and culture may result in incidences of some diseases, which have caused acute economic 
losses (Soltani \& Kalbassi 2001; Khoshbavar-Rostami, Soltani \& Hassan 2006,2007; Yang \& Li 2009; Meng, Xiao \& Zeng 2011). Persian sturgeon, Acipenser persicus, is one of the most important commercial fish species in the South Caspian Sea.

The beneficial effects of some probiotics, prebiotics, immunostimulants, and vitamin have been demonstrated in a number of previous studies in sturgeon (Falahatkar, Soltani, Abtahi, Kalbassi, \& Pourkazemi 2006; Jalali, Ahmadifar, Sudagar \& Takami 2009; Akrami, Abdolmajid, Abbas \& Abdolmohammad 2009; Jafaryan et al. 2010; Hoseinifar et al. 2011 a,b,c; Askarian, Kousha, Salma \& Ringø 2011) However, there is no information for the dietary effect of lactococcus lactis as a probiotic in sturgeon. Also, despite isolation and in some contents characterization of some lactic acid bacteria (LAB) from alimentary tract of sturgeons have reported, there is no information regarding the physiological responses of this LAB to environmental and chemical variables. The aim of the present study was to assess the growth behavior of five species of LAB consisting of Lactococcus garvieae, Weissella cibaria , Pediococcus pentosaceus, Lactococcus lactis and Enterococcus facealis isolated from Persian sturgeon fingerling intestine at different salt concentrations, temperatures and $\mathrm{pHs}$. Also, the antibacterial activity of the extracellular products of this LAB was evaluated to a virulent strain of Aeromonas hydrophila. The antibiotic resistance profiles of these LABs were also tested using some commonly used antibiotics in the aquaculture. Moreover, potential use of Lactococcus lactis (JF831150) was assessed on some growth performance, haematological and nonspecific immune response parameters of Persian sturgeon.

\section{Material and Methods}

\section{Microorganisms and Culture Conditions}

Lactococcus garvieae (JF831155), Weissella cibaria (JF831160), Pediococcus pentosaceus (JF831149), Lactococcus lactis (JF831150), and Enterococcus faecalis (JF831161) were originally isolated from intestine of Persian sturgeon (Acipenser persicus) (Soltani, Pourkazemi, Ahmadi, Taherimirghead,
Merrifield \& Masouleh 2013). A. hydrophila (A4) strain was originally isolated from diseased Persian Sturgeon (Department of Aquatic Animal Health, Faculty of Veterinary Medicine, University of Tehran, Iran). LAB strains were grown on MRS broth (Merck, Germany) incubated for overnight at 30 ${ }^{\circ} \mathrm{C}$ before analysis. A. hydrophila in TSB (Merck, Germany) incubated for overnight at $25^{\circ} \mathrm{C}$ ahead of examination.

\section{Growth Ability at Different Salt Concentration, Temperature, and $\mathbf{p H}$}

Growth ability of LAB at different environmental conditions was performed following method described by Reddy (2007), with slight modifications. The growth behavior of LAB was assessed at five different temperatures of $4,10,20,30$, and $40^{\circ} \mathrm{C}$ by inoculating into $5 \mathrm{~mL}$ MRS broth (Merck, Germany) incubated for $24 \mathrm{~h}$.

Striled MRS broth (Merck, Germany) with different pHs values of 3.7, 4.5, 5, and 6.7 (adjusted with $1 \mathrm{~N}$ HCL) (Merck, Germany) and pH 8 and 9 (adjusted with $1 \mathrm{~N} \mathrm{NaOH}$ ) (Merck,Germany) were used to evaluate the LAB growth. A volume of $100 \mu 1$ of overnight culture was inoculated to broth tubes maintained at different $\mathrm{pH}$ incubated at $30^{\circ} \mathrm{C}$ for 24 h. Also, the LAB growth was assessed at four different salinity consisting of 40, 80, 120 and $300 \mathrm{~g} \mathrm{L-1}$ $\mathrm{NaCl}$ prepared in MRB broth (Merck, Germany) inoculated with $100 \mu \mathrm{l}$ of $24 \mathrm{~h}$ culture of each LAB incubated at $30^{\circ} \mathrm{C}$ for $24 \mathrm{~h}$. The growth behavior of LABs was measured by turbidimetric assay.

\section{Antibacterial Activity of LAB Extracellular Products (ECPs)}

The agar well diffusion assay was used to detect the possible antimicrobial activity of the LAB supernatant cultures according to procedure described by Casla, Requena \& Gómez (1996) with slight modifications. Briefly, wells of $5 \mathrm{~mm}$ diameter of TSA (Merck,Germany) were loaded with $50 \mu$ of the LAB culture supernatants obtained by centrifugation (Hettich,Germany) at $10,000 \times \mathrm{g}$ for 10 $\min$ at $4{ }^{\circ} \mathrm{C}$, filtered through a $0.2 \mu \mathrm{m}$ millipore filter (Whatman ${ }^{\circledR}$, Schleicher \& Schuell) buffered at 
$\mathrm{pH}$ 6.7. The supernatant of each LAB isolate was prepared with four levels of $\mathrm{pH}$ of 6.7, 7.0, 8.0, and 9.0. Lawns of the A. hydrophila were prepared by inoculating (ca 108cells/well) in $15 \mathrm{~mL}$ of the soft-overlay (7.5 g L-1 agar) medium. The antibacterial activity of LAB ECPs against A. hydrophila (108 cells/well) was also examined at four different temperatures of $4,25,30$, and $60^{\circ} \mathrm{C}$ provided at $\mathrm{pH}$ 6.7 for 30 min using well diffusion agar and zones of growth inhibition were measured after an overnight incubation.

\section{Antibiotic Resistance Profiles}

The antibiotic resistance profiles were measured following methods described by Bello, Cocolin, Zeppa, Field, Cotter \& Hill (2012), with slight modifications. The LAB were grown in MRS broth (Merck,Germany) for an overnight at $30^{\circ} \mathrm{C}$. A volume of $20 \mathrm{~mL}$ of TSA agar (Merck, Germany) was inoculated with revitalized LAB strains ( $1 \% \mathrm{v} / \mathrm{v})$ and permitted to solidify. Antibiotic resistance pattern was determined by the disk diffusion method using oxytetracycline (30 $\mu \mathrm{g} / \mathrm{disc})$, erythromycin (15 $\mu \mathrm{g} / \mathrm{disc})$, enrofloxacin $(5 \mu \mathrm{g} / \mathrm{disc})$, florfenicol (30 $\mu \mathrm{g} / \mathrm{disc})$, flumequine ( $30 \mu \mathrm{g} / \mathrm{disc})$, and trimethoprim -sulfamethoxazol (200 $\mu \mathrm{g} / \mathrm{disc})$ (Padtan-Teb, Iran).The plates were incubated at $30{ }^{\circ} \mathrm{C}$ for $24 \mathrm{~h}$ and the zone of inhibition was measured.

\section{Fish and rearing condition}

Apparently healthy Persian sturgeon (Acipenser persicus) weighing $114 \pm 5.47 \mathrm{~g}$ were acclimated to the rearing conditions for 2 weeks at the International Sturgeon Research Institute, Guilan Province, Iran prior to the experiment. The fish were randomly divided into 4 groups each group containing 15 fish. Water quality parameters of freshwater consisting of temperature, dissolved oxygen content, and $\mathrm{pH}$ were $20.48 \pm 1.02{ }^{\circ} \mathrm{C}, 6.62 \pm 0.43 \mathrm{mg} \mathrm{L}-1$, and 6.8 7.25 , respectively.

\section{Preparation of feed with the Lactococcus lactis and feeding fish}

Preparation of feed with the Lactococcus lactis (JF831150) was according to Aly, Mohamed \&
John (2008 b) with slight modification. Briefly, the bacterium was inoculated in MRS broth (Merck,Germany) incubated for $24 \mathrm{~h}$ at $30{ }^{\circ} \mathrm{C}$ and centrifuged at $5000 \mathrm{~g}$ for $10 \mathrm{~min}$ at $4{ }^{\circ} \mathrm{C}$,. The bacterial cells were then washed three times with sterile saline to obtain a suspension of ca 1010 cells mL-1. The bacterial suspension was the sprayed into the commercial food [Biomar, $470 \mathrm{~g} \mathrm{~kg}-1$ protein, $140 \mathrm{~g}$ kg-1 lipid, $81 \mathrm{~g} \mathrm{kg-1} \mathrm{ash} \mathrm{,} 31 \mathrm{~g} \mathrm{kg-1}$ cellulose/fibre, $8.8 \mathrm{~g} \mathrm{~kg}-1$ phosphorous, $23.4 \mathrm{~g} \mathrm{~kg}-1$ calcium, $2.7 \mathrm{~g}$ kg-1 sodium, vitamin A 7500(Ui kg-1), vitamin D3 1500(Ui kg-1), copper 1.6 (mg kg-1), Magnesium 12.6 (mg kg-1), Zinc 78.6(mg kg-1), Iodine 1.9 (mg $\mathrm{kg}-1$ ), and ethoxyquin 1.9 (mg kg-1)] slowly, mixing part by part in a drum mixer to give experimental diets containing L. lactis at 106,107, and $108 \mathrm{cfu}$ g-1 diets. The pellets were air-dried at $25{ }^{\circ} \mathrm{C}$ under sterile conditions for $12 \mathrm{~h}$, packed and stored in a refrigerator $\left(4^{\circ} \mathrm{C}\right)$ until used within 3 days. The viability of the incorporated bacterial cells in the feed was assessed by CFU counting via spreading onto MRS agar (Merck, Germany). Three groups of fish (each group containing 15 fish) were fed with diets containing 106 (Treatnebt one=T1), 107 (Treatnebt one=T2), and 108 (Treatnebt one=T3) cfu g-1 of Lactococcus lactis for 56 days. The forth group was considered as control. Fish were fed 3\% biomass per day provided in equal rations at 09.00 and 17.00 h.

\section{Growth performance and carcass composition}

Growth performance was assessed in terms of condition factor (CF), specific growth rate (SGR), feed conversion ration (FCR), protein efficiency ration (PER), hepatosomatic index (HSI), weight gain (WG), initial body weight (IBW), and feed efficiency (FE). The calculations were performed using the following formulae (Merrifield, Dimitroglou, Bradley, Baker \& Davies 2009 a):

$\mathrm{CF}=\mathrm{W} \times 100 / \mathrm{L} 3 ; \mathrm{SGR}=(\mathrm{LnFW}-\mathrm{LnIW}) \times 100 / \mathrm{T}$; $\mathrm{FCR}=$ feed intake/ $(\mathrm{Wf}-\mathrm{Wi}) ; \mathrm{PER}=(\mathrm{Wf}-\mathrm{Wi}) / \mathrm{PI}$; $\mathrm{HSI}=\mathrm{LW} \times 100 / \mathrm{W} ; \mathrm{WG}=(\mathrm{Wf}-\mathrm{Wi}) ; \mathrm{IBW}=(\mathrm{Wf}-$ $\mathrm{Wi}) \times 100 / \mathrm{BWi} ; \times 100(; \mathrm{FE}=[(\mathrm{Wf}-\mathrm{Wi}) / \mathrm{FI}] \times 100$, where $\mathrm{W}$ is the weight in $\mathrm{g}, \mathrm{FW}$ is the final weight, IW is the initial weight, $\mathrm{L}$ is the length in $\mathrm{mm}, \mathrm{T}$ 
is the duration of feeding (in days), WG, is the wet weight gain, LW is the liver weight, FI is the feed intake and PI is the protein ingested. Fish were analysed according to AOAC (1995) protocols to determine carcass composition.

\section{Sample collection and analysis}

Fish samples and analysis were collected to procedures described by Aly, Ahmed, Ghareeb \& Mohamed 2008a) and Harikrishnan, Kim, Kim, Balasundaram \& Heo (2011) with slight modification. After 8 weeks feeding, nine fish were randomly collected from each treatment and blood samples were obtained from caudal vein after fish being anaesthetized with solution of tricaine methane-sulfonate (MS-222, Sigma Chemical Co., USA). The sera samples were pooled and preserved at $-20{ }^{\circ} \mathrm{C}$ or used immediately for analysis. Haematocrit levels (expressed as \% packed cell volume: \% PCV), white and red blood cells (WBC: $\times 103 \mathrm{~mm}-3$ and RBC: $\times 106 \mathrm{~mm}-3$ ), haemoglobin (Hb: g dL-1), mean corpuscular volume (MCV: fl), mean corpuscular haemoglobin (MCH:Pg), mean corpuscular haemoglobin concentration (MCHC: \%) and leukocytes were determined as lymphocytes (LYM: \%), monocytes (MON:\%), eosinophils (EOS;\%), and neutrophils (NEU:\%) following standard methods described by Merrifield et al. (2009a) and Rawling, Merrifield \& Davies (2009). The serum lactate dehydrogenate (LDH: IU mL-1), alanine aminotransferase (ALT: IU mL-1), aspartate aminotransferase (AST: IU mL-1) activities, glucose (mM), and concentration of total protein ( $\mathrm{g} \mathrm{L}-1)$ were determined using an autoanalyzer (Biotecnica Instruments, Italy). Also, serum lysozyme activity was determined according to Sahoo, Mahapatra, Saha, Barat, Sahoo, Mohanty, Gjerde, Ødegard, \& Salte (2008). Alternative complement activity (ACH50) was assayed using the method of Matsuyama, Tanaka, Nakao \& Yano (1988). The level of IgM was measured using analysis kits (Binding Site Company, www.bindingsite.co.uk) in MININEPH auto analyzer (Binding Site, UK).

\section{Statistical analysis}

One-Way ANOVA (SPSS 17.0; SPSS Inc., Chicago, IL, USA) and Duncan's test were conducted to find significant differences between treated and control trials at $\mathrm{P}<0.05$ level.

\section{Results}

\section{Bacterial growth behaviar}

All LAB isolates were able to grow at 20 and $30^{\circ} \mathrm{C}$ while no growth occurred at 4,10 and $40^{\circ} \mathrm{C}$. Also, all $\mathrm{LAB}$ isolates were able to grow at salinites 4 , and $8 \mathrm{~g} \mathrm{~L}-1(\mathrm{w} / \mathrm{v}) \mathrm{NaCl}$ with no growth at 12 and 30 g L-1 (w/v) NaCl. Furthermore, both W. cibaria and E. faecalis were able to grow at $\mathrm{pH}$ 3.7-9, while $L$. lactis and L. garvieae were able to grow at $\mathrm{pH} 5-9$ and $\mathrm{pH}$ 6-9, respectively. Interstingly the P. pentosacus could not grow above $\mathrm{pH} 7$.

\section{Antibiotic susceptibility}

Both W. cibaria and E. faecalis were resistance to the examined antibiotics while $L$. lactis exhibited sensitivity to oxytetracycline (23mm), erythromycin $(22 \mathrm{~mm})$, enrofloxacin $(21 \mathrm{~mm})$ and florfenicol (18mm). L. garvieae was also sensitive to all of used antibiotic (13-26mm) except erythromycin. $P$. pentosaceus exhibited sensitive only to oxytetracycline (11mm).

\section{Anti- Aeromonas hydrophila activity of ECPs}

The maximum antagonistic activity of 9-10 $\mathrm{mm}$ of ECPs against $A$. hydrophila were observed at temperature between 25 and $30^{\circ} \mathrm{C}$ for the ECPs of $P$. pentosaceus, L. lactis, E. faecalis while W. cibaria showed moderate activity $(7-8 \mathrm{~mm})$ at the examined temperatures and L. garvieae showed highest activity $(10 \mathrm{~mm})$ at $30^{\circ} \mathrm{C}$. The highest antagonistic activities $(9-10 \mathrm{~mm})$ were observed for the ECPs of $W$. cibaria, P. pentosaceus, and L. lactis at $\mathrm{pH} 9$ while L. garvieae and E. faecalis showed moderate activity $(7-8 \mathrm{~mm})$ at the examined $\mathrm{pH}$.

\section{Haematological and immunological parameteres} Haematocrit levels (\%PCV), MCHC, MON remained unaffected in the experimental groups. $\mathrm{WBC}$ and $\mathrm{RBC}$ counts were significantly higher in T3 than control. On the other hand, the highest HB, 
Iranian Journal of Aquatic Animal Health

Table 1 Changes of hematological parameters of Acipenser persicus fed Lactococcus lactis (JF831150) for 56 days

\begin{tabular}{lllll}
\hline Parameters & Control & $\mathrm{T} 1$ & $\mathrm{~T} 2$ & $\mathrm{~T}$ \\
\hline WBC $\left(\times 10^{3} \mathrm{~mm}-3\right)$ & $16.5 \pm 1.74^{\mathrm{a}}$ & $20.2 \pm 1.62^{\mathrm{ab}}$ & $20.3 \pm 0.64^{\mathrm{ab}}$ & $26.4 \pm 3.20^{\mathrm{b}}$ \\
RBC $\left(\times 10^{6} \mathrm{~mm}-3\right)$ & $0.50 \pm 0.08^{\mathrm{a}}$ & $0.63 \pm 0.00^{\mathrm{ab}}$ & $0.68 \pm 0.05^{\mathrm{ab}}$ & $0.72 \pm 0.05^{\mathrm{b}}$ \\
Haemoglobin $\left.(\mathrm{g} \mathrm{dl})^{-1}\right)$ & $3.50 \pm 0.09^{\mathrm{a}}$ & $3.66 \pm 0.14^{\mathrm{ab}}$ & $4.07 \pm 0.22^{\mathrm{b}}$ & $4.13 \pm 0.14^{\mathrm{b}}$ \\
Haematocrit $(\%$ PCV) & $27.9 \pm 0.72$ & $27.2 \pm 1.55$ & $25.7 \pm 1.20$ & $25.4 \pm 1.09$ \\
Mean Corpuscular Volume (ft) & $589 \pm 113^{\mathrm{b}}$ & $431 \pm 28^{\mathrm{ab}}$ & $379 \pm 21.5^{\mathrm{a}}$ & $356 \pm 32.7^{\mathrm{a}}$ \\
Mean Corpuscular Haemoglobin Concentration (\%) & $73.4 \pm 11.86$ & $58 \pm 2.85$ & $60.9 \pm 8.04$ & $57.9 \pm 5.16$ \\
Mean Corpuscular Haemoglobin (Pg) & $12.6 \pm 0.59^{\mathrm{a}}$ & $13.5 \pm 0.26^{\mathrm{ab}}$ & $15.9 \pm 1.49^{\mathrm{ab}}$ & $16.4 \pm 1.25^{\mathrm{b}}$ \\
Lymphocytes (\%) & $82 \pm 1.52^{\mathrm{b}}$ & $78.7 \pm 1.85^{\mathrm{b}}$ & $68 \pm 2.30^{\mathrm{a}}$ & $67 \pm 1.15^{\mathrm{a}}$ \\
Monocytes (\%) & $1.66 \pm 1.20$ & $1.66 \pm 1.20$ & $3.66 \pm 0.88$ & $0.66 \pm 0.33$ \\
Neutrophils (\%) & $11.7 \pm 1.76^{\mathrm{a}}$ & $16.7 \pm 0.66^{\mathrm{b}}$ & $19.3 \pm 0.88^{\mathrm{bc}}$ & $21.3 \pm 0.88^{\mathrm{c}}$ \\
Eosinophils (\%) & $4.66 \pm 1.76^{\mathrm{ab}}$ & $3 \pm 1.52^{\mathrm{a}}$ & $9 \pm 1.15^{\mathrm{bc}}$ & $11 \pm 0.57^{\mathrm{c}}$ \\
\hline
\end{tabular}

Basal diet without bacteria (Control), basal diet containing $106 \mathrm{CFUg}^{-1}$ Lactococcus lactis (JF831150) (T1), basal diet containing $10^{7}$

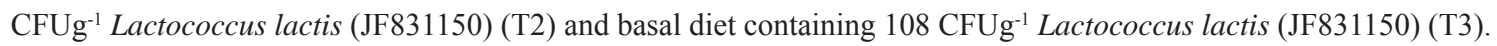

Table 2 Changes in some biochemical and immunological parameters of Acipenser persicus fed Lactococcus lactis (JF831150) for 56 days

\begin{tabular}{lllll}
\hline Parameters & Control & T1 & T2 & T3 \\
\hline Lysozyme $\left(\mathrm{U} \mathrm{mL}^{-1}\right)$ & $7.16 \pm 0.72^{\mathrm{a}}$ & $14.3 \pm 5.36^{\mathrm{ab}}$ & $19 \pm 5.56^{\mathrm{ab}}$ & $28.3 \pm 7.31^{\mathrm{b}}$ \\
Protein $\left(\mathrm{g} \mathrm{L}^{-1}\right)$ & $26.2 \pm 1.70$ & $28.50 \pm 0.80$ & $23.8 \pm 1.80$ & $23.4 \pm 4.30$ \\
Alternative complement activity $\left(\mathrm{U} \mathrm{mL}^{-1}\right)$ & $26 \pm 1.15^{\mathrm{a}}$ & $42.7 \pm 11.2^{\mathrm{ab}}$ & $53.3 \pm 5.23^{\mathrm{b}}$ & $58 \pm 7.54^{\mathrm{b}}$ \\
Lactate dehydrogenase $\left(\mathrm{IU} \mathrm{mL} \mathrm{mL}^{-1}\right.$ & $1432 \pm 398$ & $1512 \pm 112$ & $1303 \pm 53.6$ & $1174 \pm 42.9$ \\
IgM (mg dl-1) & $7.5 \pm 0.55$ & $10.8 \pm 4.25$ & $11 \pm 2.36$ & $15.1 \pm 2.80$ \\
Alanine aminotransferase $\left(\mathrm{IU} \mathrm{mL} \mathrm{mL}^{-1}\right)$ & $4.66 \pm 2.02$ & $2.33 \pm 1.33$ & $2.66 \pm 1.20$ & $1.33 \pm 0.33$ \\
Aspartate aminotransferase $\left(\mathrm{IU} \mathrm{mL}^{-1}\right)$ & $514 \pm 84.9$ & $546 \pm 17.1$ & $473 \pm 33.8$ & $404 \pm 43.2$ \\
Glucose $(\mathrm{mM})$ & $3.44 \pm 0.27$ & $3.74 \pm 0.62$ & $2.66 \pm 0.17$ & $2.85 \pm 0.47$ \\
\hline
\end{tabular}

Basal diet without bacteria(Control), basal diet containing $10^{6} \mathrm{CFUg}^{-1}$ Lactococcus lactis (JF831150) (T1), basal diet containing $10^{7}$

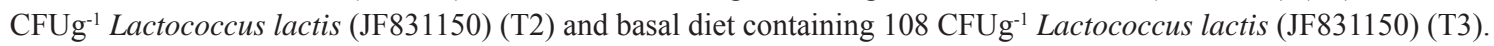

$\mathrm{MCH}, \mathrm{NEU}$ and EOS were obtained in T3, while the lowest levels were obtained in $\operatorname{control}(\mathrm{P}<0.05)$. Moreover, the MCV and LYM levels were significantly decreased in T3, while the highest levels were obtained in control (Table 1).

The total protein, LDH, IgM, ALT, AST, and glucose of the experimental groups were not significantly different from the control. Also, lysozyme, and $\mathrm{ACH} 50$ increased significantly in groups compared to control one (Table 2).

\section{Growth performance of fish}

The growth performance of fish fed with 3 levels of L. lactis is shown in Table 4. The highest growth rate was obtained in $\mathrm{T} 3$, while the lowest one was obtained in $\mathrm{T} 1(\mathrm{P}<0.05)$. The best FCR was obtained in T3 (0.96), while the highest one was ob- tained in T1 (1.11). The CF and HSI of the experimental groups were not significantly different from the control. Also, the highest SGR was obtained in T3 (1.46), while the lowest one was obtained in T1 $(1.28)(\mathrm{P}<0.05)$. The highest PER was obtained in T3 (0.48), while the lowest one was obtained in T1 $(0.42)(\mathrm{P}<0.05)$. In addition, the highest FE was obtained in T3 (103), while the lowest one was obtained in $\mathrm{T} 1$ (89.92) $(\mathrm{P}<0.05)$ (Table 3).

The highest moisture was obtained in $\mathrm{T} 2$, while the lowest one was obtained in the control $(\mathrm{P}<0.05)$. The crude protein content was significantly higher in control than experimental groups. The highest total lipid was obtained in T2, while the lowest one was obtained in control. Meanwhile, the lowest and the highest ash-content were significantly obtained in the control and $\mathrm{T} 1$, respectively (Table 4). 
Table 3 Growth performance, protein efficiency ratio, hepatosomatic index, condition factor, food conversion ratio, and feed efficiency of Acipenser persicus fed Lactococcus lactis (JF831150) for 56 days

\begin{tabular}{lllll}
\hline Parameters & Control & $\mathrm{T} 1$ & $\mathrm{~T} 2$ & $\mathrm{~T}$ \\
\hline Initial weight $(\mathrm{g})$ & $120 \pm 3.21$ & $117 \pm 5.13$ & $108.7 \pm 3.28$ & $111 \pm 6$ \\
Final weight $(\mathrm{g})$ & $257 \pm 2.68^{\mathrm{c}}$ & $239 \pm 4.07^{\mathrm{ab}}$ & $226 \pm 1.79^{\mathrm{a}}$ & $252 \pm 6.61^{\mathrm{bc}}$ \\
Weight gain (g) & $137 \pm 0.52^{\mathrm{b}}$ & $122 \pm 1.50^{\mathrm{a}}$ & $118 \pm 2.42^{\mathrm{a}}$ & $140 \pm 0.74^{\mathrm{b}}$ \\
Initial body weight (\%) & $115 \pm 3.55^{\mathrm{ab}}$ & $105 \pm 5.44^{\mathrm{a}}$ & $109 \pm 5.27^{\mathrm{a}}$ & $127 \pm 6.06^{\mathrm{b}}$ \\
Condition factor & 0.37 & 0.37 & 0.35 & $0.39 \pm 0.02$ \\
Feed Conversion Ratio & $0.98^{\mathrm{b}}$ & $1.11 \pm 0.01^{\mathrm{a}}$ & $1.15 \pm 0.02^{\mathrm{ab}}$ & $0.96^{\mathrm{ab}}$ \\
Hepatosomatic Index & $1.77 \pm 0.15$ & $2.12 \pm 0.18$ & $1.65 \pm 0.04$ & $1.80 \pm 0.37$ \\
Specific growth rate $\left(\%\right.$ day $\left.^{-1}\right)$ & $1.36 \pm 0.02^{\mathrm{ab}}$ & $1.28 \pm 0.04^{\mathrm{a}}$ & $1.31 \pm 0.04^{\mathrm{ab}}$ & $1.46 \pm 0.04^{\mathrm{c}}$ \\
Protein efficiency ration $(\%)$ & $0.47^{\mathrm{b}}$ & $0.42^{\mathrm{a}}$ & $0.40^{\mathrm{a}}$ & $0.48^{\mathrm{b}}$ \\
Feed efficiency & $101.0 \pm 0.38^{\mathrm{b}}$ & $89.9 \pm 1.10^{\mathrm{a}}$ & $86.9 \pm 1.78^{\mathrm{a}}$ & $103.0 \pm 0.54^{\mathrm{b}}$ \\
\hline Basa & &
\end{tabular}

Basal diet without bacteria (Control), basal diet containing $10^{6}$ CFUg-1 Lactococcus lactis (JF831150) (T1), basal diet containing 10

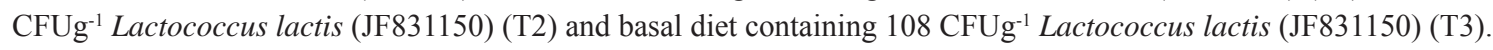

Table 4 Body proximate composition after 8 weeks feeding of Acipenser persicus fed containing Lactococcus lactis (JF831150)

\begin{tabular}{llllll}
\hline Composition $\left(\mathrm{g} \mathrm{kg}^{-1}\right)$ & Initial & Control & $\mathrm{T} 1$ & $\mathrm{~T} 2$ & $\mathrm{~T} 3$ \\
\hline Moisture & 837 & $732 \pm 1.1^{\mathrm{a}}$ & $766 \pm 4.3^{\mathrm{c}}$ & $770 \pm 1.5^{\mathrm{c}}$ & $749 \pm 2.3^{\mathrm{b}}$ \\
Crude protein & 124 & $241 \pm 0.5^{\mathrm{c}}$ & $190 \pm 4.7^{\mathrm{a}}$ & $184 \pm 2.3^{\mathrm{a}}$ & $212 \pm 4^{\mathrm{b}}$ \\
Total lipid & 17.6 & $17.5 \pm 0.2^{\mathrm{c}}$ & $26.3 \pm 1.2^{\mathrm{c}}$ & $28.3 \pm 0.6^{\mathrm{c}}$ & $22.6 \pm 1.4^{\mathrm{b}}$ \\
Ash & 12.5 & $9.6 \pm 0.6^{\mathrm{a}}$ & $12.3 \pm 0.3^{\mathrm{b}}$ & $11.6 \pm 0.8^{\mathrm{ab}}$ & $11.3 \pm 0.8^{\mathrm{ab}}$ \\
\hline
\end{tabular}

Basal diet without bacteria(Control), basal diet containing 106 CFUg-1 Lactococcus lactis (JF831150) (T1), basal diet containing 107 CFUg-1 Lactococcus lactis (JF831150) (T2) and basal diet containing 108 CFUg-1 Lactococcus lactis (JF831150) (T3).

\section{Discussion}

The in vitro growth of $\mathrm{LAB}$ at $20-30^{\circ} \mathrm{C}$ together with their resistance to acidity and alkaline conditions is correlated to the natural environmental condition of the fish intestine suggesting the isolated $\mathrm{LAB}$ are the representatives of the bacterial flora that are resident in the intestine of Persian sturgeon. For instance, the in vitro ability of some LAB including E. faecalis, P. pentosaceus, and W. cibaria to grow at low $\mathrm{pH}$ of $3.7-4.5$ is similar to the fish intestine condition that is an acidic environment. However, these results showed that all of isolated LAB had the best growth in almost neutral $\mathrm{pH}$ condition which is preferable for almost all LAB. Similar results have been reported by Holt, Krieg, Staley \& Willams (1994) and Balcazar et. al (2008) who assessed the environmental responses of some LAB such as E. faecalis, L. lactis, L. garviae and $P$. pentosaceus in the in vitro condition.

The results of present study also showed that the extracelluar products of most of isolated LAB showed a maximum inhibitory activity to A. hydrophila at $20-30^{\circ} \mathrm{C}$ indicating an optimum temperature for the production of the highest ECPs. However, L. lactis showed the highest antimicrobial activity against $A$. hydrophila similar to the results obtained by Balcazar et al. (2008) who demonstrated a strong inhibitory activity by L. lactis CLFP 101 against both $A$. hydrophila and A. salmonicida. As the best inhibitory activity due to $L$. lactis occurred at optimum physiological temperature of A. hydrophila then it is possible to recommend $L$. lactis as a suitable potential probiotic against motile Aeromonas septicemia caused by A. hydrophila in Persian sturgeon (Soltani $\&$ Kalbassi 2001). Such anti- A. hydrophila may be in part due to production of organic acids, hydrogen peroxide, carbon dioxide, acetic acid, bacteriocins, diacetyl, acetaldehyde, ethanol, and low molecular weight antimicrobial compounds e.g reuterin from some LAB (Balcazar, Vendrell, Blas, Ruiz-Zarzuela, Gironés \& Múzquiz 2007; Lee \& Salminen 2009). In addition, all examined LAB were able to keep their anti-A. hydrophila activities at $\mathrm{pH} 7$ to 9 , a property that may be a benefit tool to pass 
the gastrointestinal tract of fish. Such a character is an important factor for a bacterial strain to become a suitable probiotic because the high rate of its viability and its capacity of colonization in the fish intestine is necessary (Goktepe, Juneja \& Ahmedna 2006; Lee \& Salminen 2009).

A number of probiotics have been incorporated into aquatic animal feeds to increase the growth performances (Ghosh, Sen, \& Ray 2003; Son, Chang, Wu, Guu, Chi \& Cheng 2009; Merrifield et al. 2009a,b; Abd El-Rhman, Khattab, \& Shalaby 2009; Askarian et al. 2011).

Manipulation of intestinal microflora via probiotics plays an important mechanism for increase of growth performances and survival (Vendrell, Balcazar, Blas, Ruiz-Zarzuela, Girones \& Muzquiz 2008). However, probiotics are also effectively important of feed with detoxification and production of some hydrolytic enzymes such as amylase, protease and some vitamins like biotin as well as vitamin B12 (El-Haroun, Goda \& Chowdhury 2006). In the present study, after 8 weeks administration of the supplemented diets had a significant increase in final weight, FCR, SGR, PER, and FE of Persian sturgeon. This result is in agreement with Askarian et al. (2011) after feeding Persian sturgeon (Acipenser persicus) and Beluga (Huso huso) with Chironomidae incorporated with Lactobacillus curvatus and Leuconostoc mesenteroides for 50 days. Mechanisms of the improvement of growth performances have not completely clear but production of some vitamins like vitamin k, and B12 (Martens, Barg, Warren \& Jahn 2002) as well as extracellular enzymes such as esterase, protease, and amylase (Azokpota, Hounhouigan, Nago \& Jakobsen 2006) could have important role. Administration of probiotics enriched diets helps to improve feed utility and digestion of proteins, as well as increase the digestibility of feed resulting in increase of growth and FE (Lara-Flores, Olvera-Novoa, Guzma'n-Me'ndez \& Lo'pez-Madrid 2003). The results presented in this study revealed a significant increase in the lipid content compare to control. On the contrary, in Nile tilapia, Oreochromis niloticus (L.), fed with commercial probiotics including Bacillus subtilis and Bacillus licheniformis increase protein and decrease lipid contents (El-Haroun et al. 2006). Moreover, Merrifield et al. (2009 a,b) also reported that commercial probiotics such as B. subtilis, B. licheniformis, and Enterococcus faecium had no effect on carcass factors. Variation in lipid and protein contents in fish could be due to their synthesis and stock in muscles (Abdel-Tawwab, Khattab, Ahmad \& Shalaby 2006). Improvement of immunity using dietary enriched probiotic could be attributed to the fish species, genetic, difference in consumption time and quantity of probiotics supplementation diet, and probiotic origins (Nikoskelainen, Ouwehand, Bylund, Salminen \& Lilius 2003; Panigrahi, Kiron, Puangkaew, Kobayashi, Satoh \& Sugita 2005; Salinas, Cuesta, Esteban. \& Meseguer 2005; Kim \& Austin 2006; Pieters, Brunt, Austin \& Lyndon 2008; Son et al. 2009). The present study revealed that administration of probiotic in diets significantly enhanced the WBC, RBC, haemoglobin, $\mathrm{MCH}$, neutrophils and eosinophils. Immunocompetent cells are important for assessment of fish health and their activation and proliferation is stimulated by probiotics enriched diets (Irianto \& Austin 2002; Brunt \& Austin 2005). Leukocytes are the sources of lysozymes production (Akrami Ghelichi \& Ahmadifar 2011), and in this study a significant increase in WBC population was correlated with the enhancement of lysozyme level in fish sera. The present study also indicates that probiotics diet could decrease the Haematocrit levels (\%PCV) similar results seen Abd El-Rhman et al. (2009) who feed Nile tilapia with Micrococcus luteus and Pseudomonas species as probiotics for 90 days. Also, in this study, alternative complement activity (ACH50) was enhanced significantly in fish fed with the probiotic supplementation diet after 8 weeks. Similar results were seen in works reported by Panigrahi, Kiron, Kobayshi, Puangkaew, Satoh\& Sugita (2004); Son et al. (2009); Harikrishnan et al. (2011) and Geng et al. (2011) used some probiotics in the diets of rainbow trout (Oncorhynchus mykiss), grouper (Epinephelus coioides), rock bream (Oplegnathus fasciatus), cobia (Rachycentron canadum) and tilapia (Oreochromis niloticus).

An increase in complement components in treated 
fish sera is because of an increase in WBC population as observed in this study. Also, an increase in level of total IgM has been seen in the treated fish compared to control one $(\mathrm{P}>0.05)$ indicating of stimulating of lymphocyte population for IgM production as already reported by other researchers using some teleost fish (Salinas Abelli, Bertoni, Picchietti, Roque, Furones, Cuesta, Meseguer \& Esteban 2008; Sun, Yang, Ma \& Lin 2010).

\section{Conclusion}

In conclusion, the in vitro environmental responses of LAB recovered from the intestine of Persian sturgeon are in correlation with the physiological conditions of fish gastrointestinal tract making it possible to use some of these LABs such as L. lactis as a potential probiotic against $A$. hydrophila septicemia. However, examination of the pathogenicity of these LAB bacterial species as probiotic candidates is required prior to judging on their probiotic activity in fish. This is particularly true in case of L. garvieae that has become a universal pathogen for many fish species under different environmental conditions. Also, the results of in vitro and in vivo works here in this study clearly show that supplementation of Persian sturgeon feed with $L$. lactis as a native probiotic is able to enhance both fish growth performances and some immunophysiological responses.

\section{Acknowledgements}

This work was funded by the grant of research council of the University of Tehran, Center of Excellence of Aquatic Animal Health, University of Tehran, International Sturgeon Research Institute and Iranian Fisheries Science Research Institute.

\section{References}

Abd El-Rhman A.M., Khattab Y.A.E. \& Shalaby A.M.E. (2009) Micrococcus luteus and Pseudomonas species as probiotics for promoting the growth performance and health of Nile tilapia, Oreochromis niloticus. Fish and Shellfish Immunology 27, 175-180.

Abdel-Tawwab M., Khattab Y.A.E., Ahmad M.H. \& Shal- aby A.M.E.(2006) Compensatory growth, feed utilization, whole body composition and hematological changes in starved juvenile Nile tilapia, Oreochromis niloticus (L). Journal of Applied Aquaculture 18, 17-36.

Akrami R., Abdolmajid H., Abbas M. \& Abdolmohammad A.K.(2009) Effect of dietary prebiotic inulin on growth performance, intestinal microflora, body composition and hematological parameters of juvenile beluga, Huso huso (Linnaeus, 1758). Journal of the World Aquaculture Society 40, 771-779.

Akrami R., Ghelichi A. \& Ahmadifar E. (2011) Effect of dietary prebiotic inulin on hematological and biochemical parameters of cultured juvenile Beluga(Huso huso). Journal of Veterinary Research 66(2), 131-136.

Aly S.M., Ahmed YA-G., Ghareeb AA-A. \& Mohamed M.F. (2008a) Studies on Bacillus subtilis and Lactobacillus acidophilus, as potential probiotics, on the immune response and resistance of Tilapia nilotica (Oreochromis niloticus) to challenge infections. Fish and Shellfish Immunology 25, 128-136.

Aly S.M., Mohamed M.F. \& John G. (2008b) Effect of probiotics on the survival, growth and challenge infection in Tilapia nilotica (Oreochromis niloticus). Aquaculture Research 39, 647-656.

AOAC (1995) Official methods of analysis of AOAC International, 16th edn. AOAC International, Arlington, Virginia, USA.

Askarian F., Kousha A., Salma W. \& Ringø E. (2011)The effect of lactic acid bacteria administration on growth, digestive enzyme activity and gut microbiota in Persian sturgeon (Acipenser persicus) and beluga(Huso huso) fry. Aquaculture Nutrition 17, 488-497.

Azokpota P., Hounhouigan D.J., Nago M.C. \& Jakobsen M. (2006) Esterase and protease activities of Bacillus spp. from afitin, iru and sonru; three African locust bean (Parkia biglobosa) condiments from Benin. African Journal of Biotechnology 5, 265-272. 
Balcázar J.L., Vendrell D., Blas I., Ruiz-Zarzuela I., Múzquiz J.L. \& Gironés O.(2008) Characterization of probiotic properties of lactic acid bacteria isolated from intestinal microbiota of fish. Aquaculture 278, 188-191.

Balcázar J.L., Vendrell D., Blas I., Ruiz-Zarzuela I., Gironés O. \& Múzquiz J.L.(2007) In vitro competitive adhesion and production of antagonistic compounds by lactic acid bacteria against fish pathogens. Veterinary Microbiology 122, 373-380.

Bello B.D., Cocolin L., Zeppa G., Field D., Cotter P.D. \& Hill C.(2012)Technological characterization of bacteriocin producing Lactococcus lactis strains employed to control Listeria monocytogenes in Cottage cheese. International Journal of Food Microbiology 153, 58-65.

Brunt J. \& Austin B. (2005) Use of a probiotic to control lactococcosis and streptococcosis in rainbow trout, $\mathrm{On}$ corhynchus mykiss (Walbaum). Journal of Fish Disease 28, 693-701.

Casla D., Requena T. \& Gómez R. (1996) Antimicrobial activity of lactic acid bacteria isolated from goat's milk and artisanal cheeses: characteristics of a bacteriocin produced by Lactobacillus curvatus IFPL105. Journal of Applied Bacteriology 81, 35-41.

EL-Haroun E.R., Goda A. M. \& Chowdhury M.A.K. (2006) Effect of dietary probiotic Biogens supplementation as a growth promoter on growth performance and feed utilization of Nile tilapia Oreochromis niloticus (L.). Aquacultre Research 37, 1473-1480.

Falahatkar B., Soltani M., Abtahi B., Kalbassi M.R. \& Pourkazemi M. (2006) Effects of dietary vitamin C supplementation on performance, tissue chemical composition and alkaline phosphatase activity in great sturgeon (Huso huso). Journal of Applied Ichthyology 22, 283-286.

Geng X., Dong X., Tan B., Yang Q., Chi S., Liu H. \& Liu X. (2011) Effects of dietary chitosan and Bacillus subtilis on the growth performance, non-specific immunity and disease resistance of cobia, Rachycentron canadum. Fish and Shellfish Immunology 31, 400-406.

Ghosh K., Sen S.K. \& Ray A.K. (2003) Supplementation of an isolated fish gut bacterium, Bacillus circulans, in formulated diets for rohu, Labeo rohita, fingerlings. Israeli Journal of Aquaculture-Bamidgeh 55, 13-21.

Goktepe I., Juneja V.K. \& Ahmedna M. (2006) Probiotics in food safety and human health. CRC press, Taylor and Francis Group, USA.

Harikrishnan R., Kim M., Kim J., Balasundaram C. \& Heo M. (2011a) Protective effect of herbal and probiotics enriched diet on haematological and immunity status of Oplegnathus fasciatus (Temminck \& Schlegel) against Edwardsiella tarda. Fish and Shellfish Immunology 30, 886893.

Holt J. G., Krieg N.R., Staley J.T. \& Willams S.T. (1994) Bergeys manual of determinative bacteriology, 9th edn. Willams and Wilkins Puble.

Hoseinifar S.H., Mirvaghefi A. \& Merrifield D.L. (2011c) The effects of dietary inactive brewer's yeast Saccharomyces cerevisiae var. ellipsoideus on the growth, physiological responses and gut microbiota of juvenile beluga (Huso huso). Aquaculture 318, 90-94.

Hoseinifar S.H., Mirvaghefi A., Merrifield D.L., Mojazi Amiri B., Yelghi S. \& Darvish Bastami K.( 2011a) The study of some haematological and serum biochemical parameters of juvenile beluga (Huso huso) fed oligofructose. Fish Physiology and Biochemistry 37, 91-96.

Hoseinifar S.H., Mirvaghefi A., Mojazi Amiri B., Khoshbavar Rostami H. \& Merrifield D.L.( 2011b)The effects of oligofructose on growth performance, survival and autochthonous intestinal microbiota of beluga (Huso huso) juveniles. Aquacultre Nutrition 17, 498-504.

Irianto A. \& Austin B. (2002) Probiotics in aquaculture. Journal of Fish Disease 25, 633-642.

Jafaryan H., Taati M.M. \& Makhtoumi N.M. (2010) The effects of probiotic bacillus for promotion of growth and 
feeding parameters in beluga (Huso huso) larvae via feeding by bioencapsulated Artemia. Aquaculture, Aquarium, Conservation \& Legislation 3(4), 273-280.

Jalali M.A., Ahmadifar E., Sudagar M. \& Takami G.A. (2009) Growth efficiency, body composition, survival and haematological changes in great sturgeon (Huso huso Linnaeus, 1758) juveniles fed diets supplemented with different levels of Ergosan. Aquaculture Research 40, 804-809.

Khoshbavar-Rostami H.A., Soltani M. \& Hassan H.M.D. (2006) Immune response of great sturgeon (Huso huso) subjected to long-term exposure to sublethal concentration of the organophosphate, diazinon. Aquaculture 256, 88-94.

Khoshbavar-Rostami H.A., Soltani M. \& Hassan M.D. (2007) Immune responses of great Sturgeon (Huso huso) to Aeromonas hydrophila. Journal of Fish Biology 70(6), 1931-1938.

Kim D. \& Austin B. (2006) Innate immune responses in rainbow trout (Oncorhynchus mykiss, Walbaum) induced by probiotics. Fish and Shellfish Immunology 21, 513-524.

Lara-Flores M., Olvera-Novoa M.A., Guzma'n-Me'ndez B.E. and Lo'pez-Madrid W. (2003) Use of the bacteria Streptococcus faecium and Lactobacillus acidophilus, and the yeast Saccharomyces cerevisiae as growth promoters in Nile tilapia (Oreochromis niloticus). Aquaculture 216, 193-201.

Lee Y.K., \& Salminen S.( 2009) Handbook of probiotics and prebiotics (second edition). John Wiley and Sons, Inc., Hoboken, New Jersey.

Martens J.H., Barg H., Warren M.J. \& Jahn D. (2002) Microbial production of vitamin B-12. Applied Microbiology and Biotechnology 58, 275-285.

Matsuyama H., Tanaka K., Nakao M. \& Yano T. (1988) Characterization of the alternative complement pathway of Carp. Developmental and Comparative Immunology 12, 403-408.
Meng Y., Xiao H.B. \& Zeng L.B. (2011) Isolation and identification of the hemorrhagic septicemia pathogen from Amur sturgeon, Acipenser schrenckii. Journal of Applied Ichthyology 27, 799-803.

Merrifield D.L., Bradley G., Baker R.T.M. \& Davies S.J. (2009b) Probiotic applications for rainbow trout (Oncorhynchus mykiss Walbaum) II. Effects on growth performance, feed utilization, intestinal microbiota and related health criteria postantibiotic treatment. Aquaculture $\mathrm{Nu}$ trition 16, 496-503.

Merrifield D.L., Dimitroglou A., Bradley G., Baker R.T.M. \& Davies S.J. (2009a) Probiotic applications for rainbow trout (Oncorhynchus mykiss Walbaum) I. Effects on growth performance, feed utilization, intestinal microbiota and related health criteria. Aquaculture Nutrition 16, 504-510.

Nikoskelainen S., Ouwehand A.C., Bylund G., Salminen S. \& Lilius E.M. (2003) Immune enhancement in rainbow trout (Oncorhynchus mykiss) by potential probiotic bacteria (Lactobacillus rhamnosus). Fish and Shellfish Immunology 15, 443-452.

Oidtmann B.C., Thrush M.A., Denham K.L. \& Peeler E.J. (2011) Review. International and national biosecurity strategies in aquatic animal health. Aquaculture 320, $22-33$.

Panigrahi A., Kiron V., Puangkaew J., Kobayashi T., Satoh S. \& Sugita H. (2005) The viability of probiotic bacteria as a factor influencing the immune response in rainbow trout Oncorhynchus mykiss. Aquaculture 243, 241-254.

Panigrahi A., Kiron V., Kobayshi T., Puangkaew J., Satoh S. \& Sugita H. (2004) Immune responses in rainbow trout Oncorhynchus mykiss induced by a potential probiotics bacteria Lactobacillus rhamnosus JCM 1136. Veterinary Immunology and Immunopathology 102, 379-388.

Pieters N., Brunt J., Austin B. \& Lyndon A.R. (2008) Efficacy of in-feed probiotics against Aeromonas bestiarum and Ichthyophthirius multifiliis skin infections in rain- 
bow trout (Oncorhynchus mykiss, Walbaum). Journal of Applied Microbiology 105, 723-732.

Rawling M.D., Merrifield D.L. \& Davies S.J. (2009) Preliminary assessment of dietary supplementation of Sangrovit on red tilapia (Oreochromis niloticus) growth performance and health. Aquaculture 294, 118-122.

Reddy K.B.P.K. (2007) Effect of drying processes on viability and selected functional properties of probiotic lactic acid bacteria. $\mathrm{PhD}$ thesis, University of Mysore, India.

Sahoo P.K., Mahapatra K. D., Saha J.N., Barat A., Sahoo M., Mohanty B.R., Gjerde B., Ødegard J., Rye M. \& Salte R. (2008) Family association between immune parameters and resistance to Aeromonas hydrophila infection in the Indian major carp, Labeo rohita. Fish and Shellfish Immunology 25, 163-169.

Salinas I., Abelli L., Bertoni F., Picchietti S., Roque A., Furones D., Cuesta A., Meseguer J.\& Esteban M.A.(2008) Monospecies and multispecies probiotic formulations produce different systemic and local immunostimulatory effects in the gilthead seabream (Sparus aurata L.). Fish and Shellfish Immunology 25, 114-123.

Salinas I., Cuesta A., Esteban M.A. \& Meseguer J. (2005) Dietary administration of Lactobacillus delbrueckii and Bacillus subtilis, single or combined, on gilthead seabream cellular innate immune responses. Fish and Shellfish Immunology 19, 67-77.

Sharifuzzaman S.M. \& Austin B. (2009) Influence of probiotic feeding duration on disease resistance and immune parameters in rainbow trout. Fish and Shellfish Immunology $27,440-445$.

Soltani M. \& Kalbassi M.R.(2001)Protection of Persian sturgeon (Acipenser persicus) fingerling against Aeromonas hydrophila septicemia using three different antigens. Bulletin of the European Association of Fish Pathologists 21(6), 235 - 240.

Soltani M., Pourkazemi M., Ahmadi M.R., Taherimirghead A., Merrifield D.L. \& Masouleh A.S. (2013) Genetic diversity of lactic acid bacteria in the intestine of Persian sturgeon fingerlings. Journal of Applied Ichthyology 29(3), 494-498.

Son V.M., Chang C., Wu M., Guu Y., Chiu C. \& Cheng W.(2009) Dietary administration of the probiotic, Lactobacillus plantarum, enhanced the growth, innate immune responses, and disease resistance of the grouper Epinephelus coioides. Fish and Shellfish Immunology 26(5), 691-698.

Sun Y, Yang H, Ma R. \& Lin W.(2010) Probiotic applications of two dominant gut Bacillus strains with antagonistic activity improved the growth performance and immune responses of grouper Epinephelus coioides. Fish and Shellfish Immunology 29, 803-809.

Vendrell D., Balcazar J.L., Blas I., Ruiz-Zarzuela I., Girones O. \& Muzquiz J.L.(2008) Protection of rainbow trout (Oncorhynchus mykiss) from lactococcosis by probiotic bacteria. Comparative Immunology, Microbiology \& Infectious Diseases 31, 337-345.

Yang W. \& Li A. (2009) Isolation and characterization of Streptococcus dysgalactiae from diseased Acipenser schrenckii. Aquaculture 294, 14-17. 


\title{
فعاليث ضدباكتريايى، حساسيث آنتى بيوتيكى و استفاده بِروبيوتيك باكترى اسيد لاكتيك در برورش تاسماهى اير انى (Acipenser persicus)
}

\author{
مهدى سلطانى"'، علير ضا شناورماسوله "'، محمدرضا احمدى'، محمد يور كاظمى '، على طاهرى مير قائد'

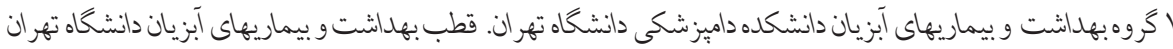

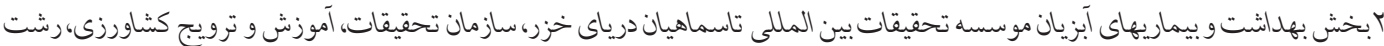

ارزيابى رفتار رشد ه باكترى اسيد لاكتيك شناسايى شده از تاسماهى ايرانى در شرايط متفاوت pH ، دمايى و شورى انجام كرفت. همجنين فعاليت

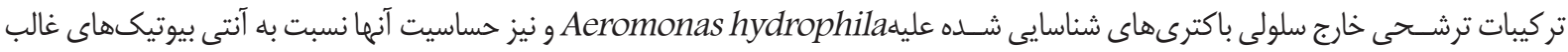

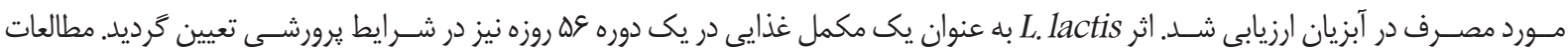

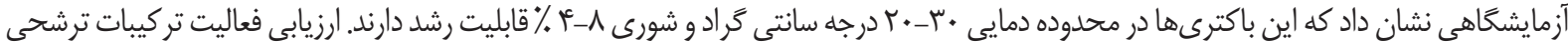

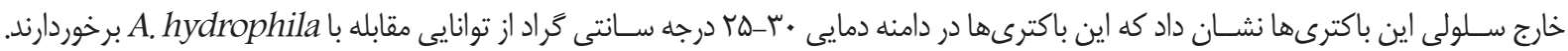

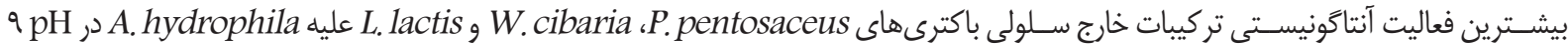
بوده است. باكترىهاى E. faecalis W. cibaria نسبت به آنتى بيوتيك هاى اكسى تتر اسايكلين، اريترومايسين،ترى متويريم سولفامتوكسازول،

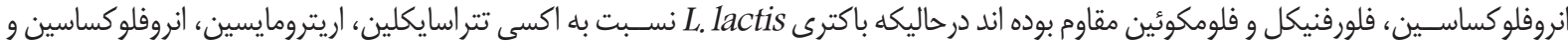
فلورفنيكل حساسيت نشان داد. نتايج اين مطالعه نشان داد كه مصرف L. lactis مىتواند در بهبود شاخصهاى رشد، كار آيى غذا و بهداشت تاسماهى ايرانى به عنوان يك يروبيوتيك احتمالى مؤثر باشد. وازههاى كليدى: ماهيان خاو يارى، بهداشت، لاكتو كو كوس لاكتيس، بروبيوتيك. msoltani@ut.ac.ir : 